\title{
An Analysis of the Influence of Parenting Style on Children's Involvement in the Decision of Purchasing Gadgets
}

\author{
(A Case Study on Junior High School Students in Purwokerto City)
}

\author{
M. Agung Miftahuddin \\ University of Muhammadiyah Purwokerto, \\ amif_ump@yahoo.com
}

\author{
Suyoto \\ University of Muhammadiyah Purwokerto, \\ amif_ump@yahoo.com
}

\begin{abstract}
This research was aimed to analyze the interaction pattern between parents and children in purchasing mobile phones/gadgets. The parental behavior is reflected through the adopted parenting style. The children's response is indicated by the strategy chosen to influence the purchase decision. The population of this research was junior high school students in Purwokerto city. The sampling technique was purposive sampling method, with criteria are as follow 1). students have mobile phones/gadgets, 2). the parents are still alive. The number of the sample was 69 people. Regression analysis and ANOVA (analysis of variance) were used to answer the hypothesis. The results indicated that parenting style did not significantly influence the involvement of children in purchasing. On the other hand, it was known that parenting style influenced the strategies used by children in order to influence purchasing decisions. Furthermore, it was also indicated that between male and female students, there was no difference in applying strategies to influence the decision.
\end{abstract}

Keywords: parenting style, children's strategy of choice, the involvement of the purchasing decision

\section{INTRODUCTION}

Data from the Ministry of Women's Empowerment and Child Protection show that in 2012 in Indonesia the number of children aged 6-17 years was approximately 82.5 million. Meanwhile, according to Frontier Marketing and Research Consultant (FMRC) in 2001 in five major cities in Indonesia, the amount of child's pocket money used for direct purchase was around $\mathrm{Rp}$ 1,850 per day. If totaled, the money spent each year could reach to 5 trillion Rupiahs. This phenomenon illustrates the huge purchasing potential of the market segment of the child; thus, it becomes the main attraction for marketers. Studies on the purchasing decision process in the family is an interesting object for researchers in the field of marketing, especially consumers' behavior. Studies that take family settings have been widely practiced, especially highlighting the role of parents, in this case husbands and wives in the family purchasing decision [1]. In the further development, the researchers focuses more on the influence of relative households, especially children in various aspects of family purchases.

Commuri and Gentry [2] argues that, in fact, the main attraction of this child market is not only purchasing ability but also because the child has become a very strong influencer in the family consumption. The greater the role of the child in the family consumption decisions, according to Assael, is driven by several factors, namely 1) the increasing number of mothers working outside the home, 2) the large proportion of single parents, and 3) the number of households that have dual earnings. The significant increase in the relative role of children in family consumption decisions is an integral part of the consumer socialization process for children.

Nowadays, the need for devices and communication tools is increasing sharply. Almost every person, whether in the countryside or in urban areas, adults, and even children, has been very familiar with the term gadget, which is a small electronic device that has a special function and always presents the latest technology that makes life more practical [3]. The purpose of using gadgets other than communicating is for playing games, internet access, email, social networking, streaming, music, video, mobile TV, games, etc.

The use of gadgets / mobile phones among children based on research results initiated by UNICEF and Ministry of Communications and Informatics of the Republic of Indonesia (2012) on 400 children and adolescent respondent saged 10-19 years, shows that 208 people $(52 \%)$ of respondents used mobile phones to not only communicate with their friends but also to access the internet. This fact indicates that children have become a potential market; and on that ground, for a socialization to become rational and intelligent. Consumers, it is important to do conduct analysis on how the pattern of interaction between children and parents in the process of making purchasing decisions, especially on mobile phones / gadgets products. Carlson and Grossbart [4] states that although parents may differ in their supervision and socialization, the 
assumption is that their primary roles are influencing, teaching, and supervising their children. Some studies have suggested that parenting style is indicated to be

closely related to the patterns and variations of parental interactions in teaching and influencing their children in making requests for a product from their parents [5]. [6] states that children (adolescents) through interaction with their parents will seek to influence the outcome of purchasing decisions by applying various strategies. Cowan, [7] categorize strategies used by children into three dimensions: directness (straightforward), bilaterality (agreement) and strength (forcing).

This research aims at analyzing the influence of parenting style patterns on the involvement of children in the process of purchasing mobile phones (A study on junior high school students in Purwokerto). The children will respond their parents through applied implementing specific strategies so that the final decision of the purchasing process allows satisfaction for both parties.

\section{METHOD}

The objects of this research were parenting stylesleading to the involvement of children in the process of decision making of purchasingmobile phones / gadgetsin junior high school students in Purwokerto City.

The population in this study was junior high school students in Purwokerto city. Samples were taken using a purposive sampling method, i.e. sampling done with certain criteria in order to answer the research problem. The first criterion was that the students had to own a gadget (mobile phone). The second criterion was that thestudents' parents (mother and/or father) are still alive, in which it would allow them to have aninteraction pattern with theirparents. The number of samples was 76 students.

The data used in this study consisted of primary data and secondary data. The primary data were used as material to calculate the research variables. The primary data collection was carried out by questionnaires about parent-childeren interaction; as directly stated byRussoand Owens in Miftahuddin (2005), interaction between parents and children can be defined as a reciprocal communication process or combination of actions between parents and children whicht hey affect each other.

Multiple regression equation model was used to analyze the correlation of variables in this research. The dependent variable was the relative influence of the children in the purchasing decision of the family, while the parenting style was the independent variable. The children's choice influence strategy was treated as a process variable because, in addition to being a dependent variable, it was also an independent variable. In addition to regression analysis, the study also used variance analysis, which was performed to determine the difference of mean scores in two groups or more. In this study one-way variance analysis (one-way ANOVA) was used to answer the third research question.

\section{RESULT}

This research used survey method, i.e.the research was done by distributing questionnaires to respondents. Respondents in this study were students of Junior High School (SMP) in Purwokerto. Sampling was taken using the purposive sampling method. The number of questionnaires distributed to respondents was 76 copies with a response rate of $90.7 \%$.

Table 1 Characteristics of the Respondents

\begin{tabular}{lll}
\hline \multicolumn{1}{c}{ Characteristics } & F & $\%$ \\
\hline School & & \\
SMP Muh 1 & 14 & 203 \\
SMP Muh 3 & 13 & 18.8 \\
SMP N 2 & 13 & 18.8 \\
SMP N 5 & 14 & 20.3 \\
SMP N 8 & 15 & 21.8 \\
\hline Birth Year & & \\
1998 & 1 & 1.4 \\
1999 & 4 & 5.9 \\
2000 & 23 & 33.3 \\
2001 & 28 & 40.6 \\
2002 & 11 & 15.9 \\
2003 & 2 & 2.9 \\
\hline Gender & & \\
Male & 38 & 55.1 \\
Female & 31 & 44.9 \\
\hline
\end{tabular}

The research analysis unit was junior high school students (SMP) in Purwokerto. Based on the data collected through questionnaires, the characteristics of respondents is described in the following table 1.

Based on the table above, it is described that the samples comprise 38 male students $(55.1 \%)$ and 31 $(44.9 \%)$ female students. In terms of school participation, the highest samplesare from SMP N 8 with 15 people or $21 \%$, the rests are from SMP Muhammadiyah 1 and SMPN 5; 14 people $(20.3 \%)$, and 13 people $(18.8 \%)$ are SMP Muhammadiyah 3 and SMP N 2 respectively. In terms of age, there was 1 person who is 16 years (born in 1998), and mostly are 15-year- oldstudents (born in 2001 ) with the number of students as many as 28 people $(40.6 \%)$. The study also looks into the number of families of respondents and the duration of using mobile phones / gadgets. Out of 69 respondents, there are $39.1 \%$ or 27 people having 2 siblings, and 23 other people more than 3 siblings. This indicates that the average respondents have older and younger siblings. Therefore, it isestimated to have an effect on the pattern of interaction between children and parents that occurs when making purchasing decisions. If reviewed based on the ownership length of mobile phones, it is known that more than half of students have been using it for more than 12 months, and Samsung brand is the most used mobile phone by $31.9 \%$ respondents.

\section{Hypothesis Testing 1}

The first hypothesis testing ismeasured by regression analysis in order to see if there is influence of parenting 
style applied by parents on the involvement of children in purchasing mobile phones / gadgets.

Based on the test result that the significance value of 0.738 was higher than the alpha $(\alpha) 5 \%$, so it could be concluded that parenting style did not significantly influence the involvement of children in making purchasing decisions.

\section{Hypothesis Testing 2}

The second hypothesis testing is to test whether there is an influence of parenting style applied by parents on the influencing strategy applied by the children or not, this is also done employing regression analysis. The test result shows that the significance value is 0.000 , lower than the $5 \%$ alpha level. Therefore, it can be concluded that parenting style applied by parents has a significant influence on strategies used by children in an effort to influence the purchasing decisions.

Table 2: Result of Regression of the Second Hypothesis

Coefficients ${ }^{\mathrm{a}}$

\begin{tabular}{|c|c|c|c|c|c|c|}
\hline \multirow{2}{*}{\multicolumn{2}{|c|}{ Model }} & \multicolumn{2}{|c|}{$\begin{array}{l}\text { Unstandardized } \\
\text { Coefficients }\end{array}$} & \multirow{2}{*}{$\begin{array}{c}\text { Standardized } \\
\text { Coefficients }\end{array}$} & \multirow[b]{2}{*}{$t$} & \multirow[b]{2}{*}{ Sig. } \\
\hline & & B & Std. Error & & & \\
\hline 1 & (Constant) & 1.684 & .260 & & 6.467 & .000 \\
\hline & reratacl & .502 & .081 & .605 & 6.211 & .000 \\
\hline
\end{tabular}

\section{Hypothesis Testing 3}

Testing of the third hypothesis is to find out whether there is a difference between male and female students in using strategies in an effort to influence the purchasing decision process. This testing is done with Anova test of which results are seen in the following table 3 .

Based on table 3, it is indicated that the significance value is 0.328 ; this is higher than the $5 \%$ alpha value. Thus, between male and female students there is not any significant difference in responding to the parenting style applied by their parents.

This study aims at analyzing the involvement of children (students in this case) relatively in the decision to purchase mobile phones / gadgets by trying to identify the process of interaction between children and their parents. The search for the influence of parenting style on the involvement of children in purchasing is in accordance with the first hypothesis. The regression analysis shows a significance value of 0.738 higher than the 5\% alpha level. Therefore, it was concluded that parenting style does not significantly affect the involvement of children in purchasing decisions of mobile phones / gadgets. In this regard, various studies show that mixed results, even [8] have failed to reveal the influence of parenting style on the involvement of children in purchasing [9].

The application of children's strategies to influence the choice [10]is a reflection of parenting style strategies adopted by parents. The results of this study indicates the suitability with Wilkes' opinion; the findings of the analysis reveal a significance level of 0.000 of which value is lower than the level of 5\% alpha.

The analysis is to reveal the hypothesis stating that there is a difference between boys and girls in using strategies to influence purchasing decisions; in order to find it out, ANOVA analysis is used. The result is that there is no difference between the male and female students in responding to the parenting style applied by their parents.

Table 3 Result of Anova Testing

\begin{tabular}{|c|c|c|c|c|c|c|}
\hline \multicolumn{7}{|c|}{ ANOVA Table } \\
\hline & & $\begin{array}{l}\text { Sum of } \\
\text { Suwares }\end{array}$ & $d f$ & Nean Square & $\mathrm{F}$ & \\
\hline reratac| * Jenis Kelamin & $\begin{array}{l}\begin{array}{l}\text { Between Groups } \\
\text { Within Grombined) } \\
\text { Total }\end{array} \\
\end{array}$ & $\begin{array}{r}2.275 \\
19.013 \\
19.288 \\
\end{array}$ & $\begin{array}{r}1 \\
67 \\
68\end{array}$ & $\begin{array}{l}.275 \\
.284\end{array}$ & .969 & .328 \\
\hline
\end{tabular}

This is indicated by a significance value, which is higher than 5\% alpha level. [11] is more directed to examine the age difference on children and its relationship with strategies they use.

\section{CONCLUSION}

Parenting style variables do not significantly influence the level of involvement of children in purchasing decisions of mobile phones / gadgets. This is shown through regression analysis, where the significance value of 0.738 , higher than the alpha level set at 5\%.Parenting style is indicated to have a significant effect on the strategies used by children in trying to influence the decision of purchasing mobile phones / gadgets. Regression results show a signification value of 0.000 lower than the specified alpha level of 5\%.Another finding is that there is no significant difference between boys and girls in implementing strategies to influence the decision of purchasing mobile phones/ gadgets in the family.

\section{Implications}

Parenting style and children's choice strategies are factors that influence each other. Hence, anything done by parents in educating and interacting with children to be smart and mature consumers should be done well and the age range of children should also be taken into account. Although there is no significant difference between boys and girls in the use of strategies in influencing purchasing decisions, parents need to further understand the behavior patterns of their children, so it can provide fair and proportional treatment according to the level of each individual needs.

\section{REFERENCES}

[1] Assael, Henry. Consumer Behavior and Marketing Action, International Thomson Publishing, Cincinati, Ohio, USA. 1998.

[2] Commuri, Suraj dan Gentry, James W. "Opportunities for family research in marketing," Academy of Marketing Science. 2000.

[3] Cowan, Gloria; Joan Drinkard dan Laurie McGavin, "The effect of target, age and gender on use power strategies," Journal of personality and social psychology, 38, (4), 618-628. 1994.

[4] Carlson, Les dan Grossbart, Sanford ,Parental style and consumer socialization of children,"Journal of Consumer Research, 15 (Juni): 77-94. 1998. 
[5] Darling, Nancy. "Parenting style and its correlates. Erict Digest, www.ericfasility.net/database. 1999.

[6] Kementerian Pemberdayaan Perempuan dan Perlindungan Anak, Daftar Profil Anak Indonesia tahun, Jakarta. 2012.
[7] Miftahuddin, M. Agung). Pengaruh Parental Style dan penghasilan orang tua terhadap keterlibatan anak dalam pembelian keluarga, Thesis. 2005.

[8] Wilkes, Robert E. "Adolescent-parent interaction in family decision making," Journal of Consumer Research, Vol. 24: 159-169. 1997. 